\title{
Ataxioceras (Ataxioceras) lopeztichae Cantú-Chapa, 1991: Updating the systematic and palaeobiogeographic interpretation
}

\author{
Luis Moliner, Federico Olóriz, and Ana Bertha Villaseñor
}

\begin{abstract}
Common, recurrent and pervasive homeomorphism makes precise biostratigraphy crucial for correct interpretations of Lower Kimmeridgian ataxioceratin ammonites (e.g., Ataxioceras Fontannes, 1879 and Ataxioceras [Schneidia] Atrops, 1982) on the basis of analyzing complete specimens. Ataxioceras is not conclusively known even in epicontinental, Submediterranean areas since the majority of nominal species were erected during pioneer times for ammonite systematics and biostratigraphy, and updated information is really limited. Reports of Ataxioceras from Mexico reveal that the material is not conclusive for accepting these records as real occurrences, which is corroborated by hundreds of specimens retrieved from outcrops sampled bed-by-bed during the last two decades. The potential occurrence of Ataxioceras in Mexico is approached through the analysis of the single, complete, in-volume preserved specimen illustrated as Ataxioceras (Ataxioceras) lopeztichae sp. nov. by Cantú-Chapa, 1991, and the revision of its systematic and palaeobiogeographic meaning is made. The precise analysis of shell morphology, ribbing and peristomal structure has been supported with complementary comparisons with involute morpho-species of Ataxioceras and Schneidia. Reinterpretation of the Mexican type as Schneidia lopeztichai (Cantú-Chapa) of a latest Platynota to earliest Hypselocyclum age is promoted, and favoured its occurrence in relation with colonization events under Hispanic Corridor influence. A potential western colonization by Early Kimmeridgian ataxioceratins via the Panthalassa Ocean is not supported by reported records of assumed Ataxioceras from north-easternmost Gondwana and terrane complexes accreted to the easternmost Asian Block since they refer to unidentified homeomorphs.
\end{abstract}

Luis Moliner. ENSAYA Laboratory, Aneto n 8, Cuarte de Huerva, Zaragoza, 50410, Spain, luis.moliner1982@gmail.com

Federico Olóriz. University of Granada, Department of Stratigraphy and Paleontology, Av. Fuentenueva s/ n, Granada, 18071, Spain, foloriz@ugr.es (corresponding author)

Ana Bertha Villaseñor. Universidad Nacional Autónoma de México, Instituto de Geología, Departamento de Paleontología, Cd. México, 04510, Mexico, anab@unam.mx

Keywords: Ammonites; systematics; paleobiogeography; Kimmeridgian; Mexico

Submission: 17 August 2015. Acceptance: 16 May 2016.

Moliner, Luis, Olóriz, Federico, and Villaseñor, Ana Bertha. 2016. Ataxioceras (Ataxioceras) lopeztichae Cantú-Chapa, 1991: Updating the systematic and palaeobiogeographic interpretation. Palaeontologia Electronica 19.2.19A: 1-16

palaeo-electronica.org/content/2016/1485-ammonites-kimmeridgian-mexico 


\section{INTRODUCTION}

Reports of Lower Kimmeridgian ataxioceratin ammonites in Mexico are known from northeastern, central-east and southern Mexico based on subsurface material retrieved from bore holes, and samples gathered from both outcrops and sections analyzed bed-by-bed (e.g., Cantú-Chapa, 1969, 1971, 1979, 1984, 1991, 1992, 2001; Villaseñor, 1991; Villaseñor et al., 2000; López-Caballero, 2009; Jiménez-López, 2011; Villaseñor et al., 2012, 2014, 2015) . Interpretations in these reports include: (i) thickness variations among 5 and 235 $\mathrm{m}$ for the stratigraphic interval containing the alluded ammonites, at least for eastern Mexico; (ii) biostratigraphic interpretations in terms of the "Unidad or Zona con Ataxioceras" and then of the "Schneidia Assemblage", but references to informal biostratigraphic intervals have been also considered; (iii) assumed scarce and inconclusive, controversial occurrence of raseniid ammonites; (iv) increasing reference to the occurrence of Schneidia; (v) correlation with biostratigraphic scales for southern Submediterranean Europe, mainly pointing to imprecise intervals of the Platynota and Hypselocyclum zones; and (vi) alternative paleobiogeographic interpretations about Mexican Lower Kimmeridgian ataxioceratins.

Except for Cantú-Chapa (1992), a throrough revision of these reports can be found in Villaseñor et al. (2015), who were focused on the analysis of 267 ataxioceratins recorded bed-by-bed from a 11 $\mathrm{m}$ thick section in north-central Mexico (Figure 1). The material illustrated by Cantú-Chapa (1992, pl. 1 , figs. $1,3,6,9,10,14$ and 19) is composed of incomplete ammonite specimens and fragments that represent a material affected, at least in part, by sample diameter when gathered from borehole cores-all pictured specimens except those in figures 14 and 19, which have no indication to have been recorded as subsurface samples. The reported ammonites are Ataxioceras (Schneidia) sp. (ibid., pl. 1, figs. 1, 3), Lithacosphinctes sp. (ibid., pl. 1, fig. 6), Ataxioceras (Ataxioceras) aff. subinvolutum (Siemiradski; recte Siemiradzki) (ibid., pl. 1 fig. 9), Rasenia aff. (Rasenioides) sp. (ibid., pl. 1, fig. 10), Ataxioceras (Parataxioceras) sp. (ibid., fig. 14), and Ataxioceras (Ataxioceras) sp. (ibid., pl. 1, fig. 19). All these ammonites were interpreted to belong to the "Zona con Ataxioceras". Incompleteness and/or poor preservation of these ammonites only allow to approach their interpretation as ataxioceratins. Among these ammonites, Rasenia aff. (Rasenioides) sp. (ibid., pl. 1, fig. 10) is an isolate record from a $5 \mathrm{~m}$ thick strati-

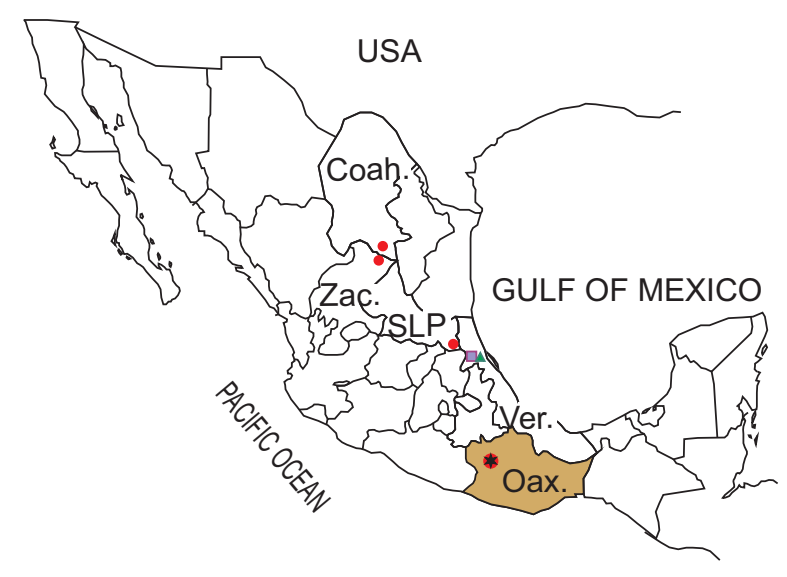

FIGURE 1. Map of Mexico with approximate locations for reported records of Lower Kimmeridgian ataxioceratin ammonites mentioned in text, with reference to Mexican states. Light brown (Oaxaca state). Black star (town of Tlaxiaco at the surroundings of which Schneidia lopeztichai [Cantú-Chapa] was found). Red dots (north-to-south surface records reported and illustrated by López-Caballero, 2009 from Coahuila; Villaseñor, 1991 and Villaseñor et al., 2000, 2015 from Zacatecas; Cantú-Chapa, 1984 and Jiménez-López, 2011 from San Luis Potosí; and Cantú-Chapa, 1991 from Oaxaca). Green triangle (subsurface record reported and illustrated from Veracruz by Cantú-Chapa, 2001). Purple square (subsurface records reported without illustration by Cantú-Chapa, 1969, 1971).

graphic interval recorded from a subsurface core, and is too incomplete and poorly preserved to be conclusively interpreted.

The present paper revises the status of Ataxioceras (Ataxioceras) lopeztichae Cantú-Chapa, 1991, the single, illustrated specimen of complete Lower Kimmeridgian ataxioceratin ammonite preserved in volume from Mexico-Villaseñor et al., 2015, fig. 5) illustrated a single phragmocone preserved in volume among slightly more than 300 specimens analyzed. According to Cantú-Chapa (1991, p. 20), the type is housed in the author's collection with label Ac-1003. Unfortunately, no success was obtained with an institutional petition to analyze the specimen or to have a plaster cast on March 12, 2014, hence only indirect, computer image-analysis of the type under study was available for this revision (Figure 2). In order to proceed with additional, comparative analyses with Lower Kimmeridgian European ataxioceratins, measurements were obtained from papers of the different authors, or they were directly gathered from measurements made on their illustrations (see below) to support bivariate plots included in this paper. There were identified cases in which some devia- 

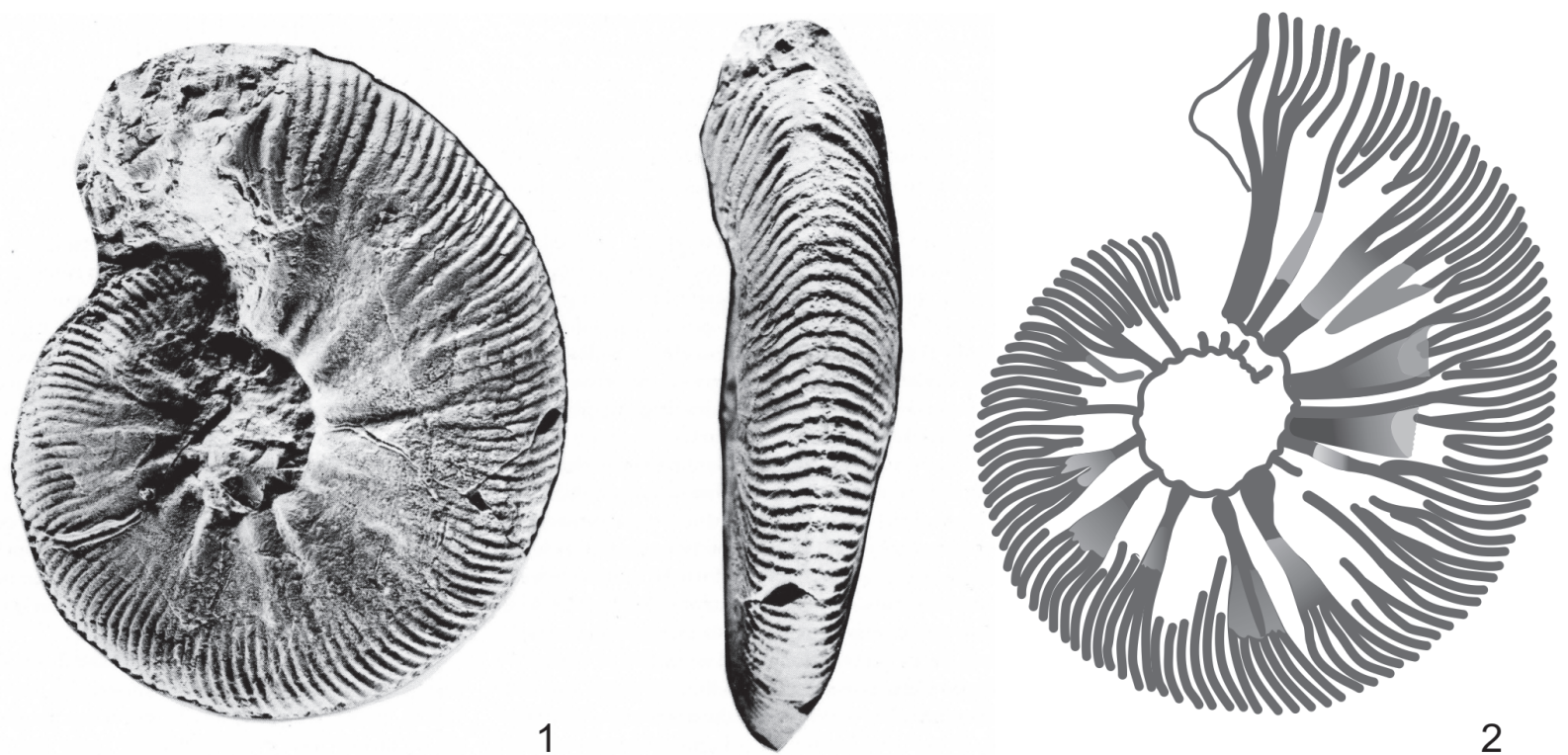

FIGURE 2. 1 - Type of Ataxioceras (Ataxioceras) lopeztichae as illustrated by Cantú-Chapa (1991), and re-interpreted as Schneidia lopeztichai (Cantú-Chapa); reproduced with permission of the Revista Mexicana de Ciencias Geológicas. 2 - Ribbing pattern of Schneidia lopeztichai (Cantú-Chapa) obtained from computer image-analysis showing sculpture relief according to the degree of shading (dark to light for higher to lower relief) and white for inter-ribs and depressed spaces.

tions became apparent among the data provided in text by the given authors and those obtained from their illustrations, as well as illustrations for which no scale and/or no measurements were provided (e.g., in some of the old papers mentioned throughout this paper). This limitation with data obtained from illustrations was surpassed by using U/D ratios (i.e., the size of the umbilicus vs. shell size, measured in millimetres) for evaluation of coiling degrees; maximal fluctuations greater than $3-5 \%$ in the obtained values are indicated.

Given that the most recent information about Mexican ataxioceratins was obtained from material preserved as crushed inner casts of more or less incomplete specimens and fragments collected bed-by-bed, and focused on interpretations at the population level, precise biostratigraphy, and evaluation of the correlation potential (Villaseñor et al., 2015), the special interest recognized for reviewing the Cantú-Chapa's type is twofold: (i) to analyze the single, complete ataxioceratin ammonites reported from the lowermost Kimmeridgian horizons documented in Mexico, allowing a precise study of the adult stage in order to clarify its systematic interpretation; and (ii) to evaluate the hypothesis of colonization of Mexican seas being achieved by "paleo-Pacific" ataxioceratins across a southern passage early during Kimmeridgian times
(Cantú-Chapa, 1991), which was proposed on the basis of the type here revised.

\section{Remarks on Ataxioceras (Ataxioceras) lopeztichae sp. nov. Cantú-Chapa, 1991}

Ataxioceras (Ataxioceras) lopeztichae was erected by Cantú-Chapa (1991) without indication of the precise stratigraphic level of provenance. Thus, the interpretation made by this author of the specimen he analyzed was necessarily limited to the analysis of shell features, such as sculpture and coiling, and no details about the state of preservation were given. Shell measurements in CantúChapa (1991, p. 18) gave $10.8 \mathrm{~cm}$ for shell size, $2.4 \mathrm{~cm}$ for the size of the umbilicus, and $0.22 \%$ (recte $22 \%$ ) for the coiling degree. Concerning the sculpture, Cantú-Chapa (op. cit.) assumed the occurrence of real polyplocoid ribs ("el tipo de costillas corresponde a una forma evolucionada del denominado costillaje poliplocoide...la primera bifurcación se efectúa hacia la mitad de los flancos y la segunda, en el tercio externo"; cf. CantúChapa, 1991, p. 18; sic). Cantú-Chapa (1991, p. 18) rightly identified the occurrence of lappets, but he did not use this feature for his interpretation at the genus level.

Based on computer image-analysis after digitize figure 2 in Cantú-Chapa (1991), and the experience on ammonite preservation in the lowermost 
Kimmeridgian deposits overlying Zuloaga carbonates and lateral equivalents in Mexico (e.g., Olóriz et al., 1997; Villaseñor et al., 2015), we assume inner cast preservation for the specimen described by Cantú-Chapa (1991). It is well known that innercast preservation in siltstones commonly forces some degree of sculpture smoothing-i.e., ribs' smoothing in the case under consideration.

In order to characterize the ribbing pattern in the specimen gathered from SW Tlaxiaco, Oaxaca, in a way as precise as possible, we proceeded with careful analysis of the digitized figure 2 in CantúChapa (1991) under computer image-analysis. Our results show neither clear points of rib-connection ("division") at the mid flank and on, or close to, the umbilical edge, nor real polyplocoid ribs. In contrast, a rather irregular ribbing was revealed in which fasciculate-like ribs ("costulation subfasciculée" in Atrops, 1982) and palmate-like ribs ("diversipartite-fascipartite rippenspaltung" Geyer, 1961; "côte palmée" Atrops, 1982 and Hantzpergue, 1989; "division fasciculée" Hantzpergue, 1989) are typical, together with common and irregularly developed intercalatory ribs (Figure 2.1-2). The obtained ribbing index, considered as the number of peripheral, secondary ribs per ten periumbilical, primary ones (see Geyer, 1961; Atrops, 1982; Moliner, 2009; among others), was high (7.1).

It is a well-known fact that phenotype convergence (homeomorphism) among Lower Kimmeridgian ataxioceratins forces potential misinterpretations of specimens collected without precise biostratigraphic control. This applies to genera and/ or subgenera such as Schneidia and Ataxioceras collected from horizons close to the Platynota/ Hypselocyclum zone boundary and from the upper Hypselocyclum Zone, respectively (cf. Atrops, 1982; Moliner, 2009), as well as to other epicontinental records of ataxioceratin ammonites of Kimmeridgian age (e.g., Hantzpergue, 1989; Moliner and Olóriz, 2010).

Cantú-Chapa (1991, p. 19) recognized morphological affinity between his specimen of Atax. (Atax.) lopeztichae and the European Atax. (Atax.) subinvolutum Siemiradzki illustrated by Geyer (1961, pl. 12, fig. 2). Their morphological affinity was mainly stated in terms of the coiling degree since the primary ribs were considered to be coarser and more numerous in the Mexican specimen. In fact, the specimen illustrated by Geyer (op. cit) is clearly more evolute (U/D 31\%) than Atax. (Atax.) lopeztichae Cantú-Chapa (U/D 22\% in Cantú-Chapa, 1991, p. 18), and shows a rather irregular ribbing in which true polyplocoid ribs seems to be rare (see below). The latter contrasts with that stated by Geyer (1961, p. 57) when typifying Atax. (Atax.) subinvolutum Siemiradzki, but it was in accordance with the ribbing pattern illustrated by this author (Geyer, 1961, fig. 70-71). It is worth mentioning that the alluded specimen of Atax. (Atax.) subinvolutum Siemiradzki illustrated by Geyer (1961, p. 12, fig. 2) was reinterpreted by Atrops (1982) and included in Atax. hypselocyclum Fontannes, together with the holotype of Atax. subinvolutum Siemiradzki illustrated by Geyer (1961, pl. 12, fig. 1; see also Schlegelmich, 1994, pl. 32, fig. 1; and precise comments later in text). The latter is also more evolute (U/D 31-33\%) and shows a ribbing style that seems to be less irregular than it is in Atax. (Atax.) lopeztichae (Cantú-Chapa, 1991). Moliner (2009) reinterpreted the specimen of Atax. (Atax.) subinvolutum Siemiradzki illustrated by Geyer (1961, pl. 12, fig. 2) as a macroconchiate specimen of Ataxioceras lothari (Oppel) morph. lothari Oppel (substitution of the name hypselocyclum by priority). In addition, a more evolute specimen (U/D 33\%) illustrated by Geyer (1961, pl. 10, fig. 6) as Atax. (Atax.) subinvolutum Siemiradzki was later reinterpreted as Atax. (Schneidia) lussasense by Atrops (1982).

Cantú-Chapa (1991, p. 19) interpreted Atax. hypselocyclum Fontannes in Atrops (1982) as being more evolute and finely sculptured that his Atax. (Atax.) lopeztichae.

In conclusion, Atax. (Atax.) lopeztichae CantúChapa was compared by Cantú-Chapa (1991) with specimens that were previously reinterpreted by Atrops (1982) as Atax. (Atax.) hypselocyclum Fontannes (= Atax. lothari [Oppel] morph. lothari Oppel, macroconch in Moliner, 2009) and Ataxioceras (Schneidia) lussasense, a taxon in which Atrops (1982) included several species of Ataxioceras erected by Siemiradzki (1898) and Schneid (1944). Hence, this case shows how the phenotype of Atax. (Atax.) lopeztichae Cantú-Chapa can be considered morphologically comparable to, and difficult to distinguish of, taxa belonging to different stratigraphic horizons within the Lower Kimmeridgian, uppermost Platynota to Hypselocyclum zones.

In an earlier paper, Cantú-Chapa (1969) reported, without illustration, Ataxioceras (Ataxioceras) aff. subinvolutum (Siemiradzki) and Ataxioceras guentheri (Oppel)-written as Atax. (Atax.) aff. quenther (Oppel)-obtained from subsurface cores in Poza Rica, Veracruz. These two European species were later interpreted as Atax. (Schneidia) lussasense, at least in part (Atrops, 1982). 
We assume the well-known fact that the lack of precise biostratigraphy poses serious limitations for any interpretation of ammonites at the genus and/or species level when the analysis is based on mere morphological grounds.

\section{A COMPARATIVE ANALYSIS OF ATAXIOCERAS (ATAX.) LOPEZTICHAE CANTÚ-CHAPA, 1991 AND MORPHOLOGICALLY RELATED LOWER KIMMERIDGIAN SPECIES OF ATAXIOCERATIN AMMONITES}

A comparative analysis of Atax. (Atax.) lopeztichae Cantú-Chapa with morphologically close taxa can be approached through evaluation of selected traits in several "species" of rather involute Ataxioceras illustrated by authors such as Wegele (1929), Schneid (1944), Geyer (1961), Atrops (1982), and Schlegelmich (1994), and the most recent revision of Lower Kimmeridgian ataxioceratins provided by Moliner (2009). Bivariate plots of primary rib curves (UR) vs. shell diameter (D), and the number of primary ribs (UR) vs. coiling degree $(U / D)$ are shown in Figures 3 and 4.

\section{Remarks on European specimens originally interpreted as belonging to the genus Ataxioceras and collected without indication of intra-biozone level biostratigraphy}

Ataxioceras guentheri (Oppel) in Wegele (1929, pl. 8 [12], fig. 6). When compared with Ataxioceras (Atax.) lopeztichae Cantú-Chapa shows similar but more crowded, irregular ribbing with obscure points for rib connections between the umbilical edge and the mid-flank, and is more evolute (calculated U/D 26-26.7\% and $\mathrm{U} / \mathrm{H}$ 0.628; no measurements were included in Wegele, 1929). Although a potential polyplocoid rib seems to be preserved on the last quarter of the outer whorl preserved (body chamber?), sculpture weakening or smoothing just below the mid-flank makes difficult the precise interpretation of rib connections ("divisions"). Based on comparisons made with ataxioceratins collected bed-by-bed in SE France, Atrops (1982) interpreted the mentioned specimen as Ataxioceras (Schneidia) lussasense, a new species of the subgenus he erected. This author gave special mention to the fact that subpolyplocoid ribs were progressively longer, higher on the flank during the later ontogeny. Hence, these ribs resulted "rappelant...côtes polyploïdes” (Atrops, 1982, p. 177). However, this author also reported real polyplocoid ribs in the subgroup of Atax. (Schneidia) lussasense Atrops showing a more crowded ribbing, as well as their occurrence in the subgroup with a more irregular and less crowded ribbing where "doubles bifurcations sont realisées de façon très diverse" (Atrops, 1982, p. 178, 180). Both the coiling degree and the ribs' crowding in the Wegele's type are within the range shown in Figure 4 for specimens of Schneidia lussasense Atrops with coiling values close to the average but less crowded ribbed.

Specimens interpreted as Atax. (Atax.) guentheri (Oppel) in Geyer (1961, pl. 12, figs. 5 to 7 ). Specimens interpreted as Atax. (Atax.) guentheri (Oppel) in Geyer have a calculated coiling degree of at least $25-36 \%$ (which does not differ significantly from the range of values given by Geyer, 1961), and only those specimens developing common, shallow constrictions (e.g., Geyer, 1961, pl. 12, fig. 5) show irregular ribbing that resembles that recorded in the greater sized specimen of Atax. (Atax.) lopeztichae described by CantúChapa (1991). Some specimens assigned to the Oppel's species and illustrated by Geyer (1961, pl. 12, figs. 6 and 7) show lower whorl height and clearly more evolute shells (U/D $26 \%$ up to ca. $36 \%$ ). The specimen illustrated by Geyer (1961, pl. 1 , fig. 5) shows high values of coiling degree (U/D $28.5-31.5 \%$ ), lesser degree of weakening or smoothing of the sculpture at the mid-flank, and neither subpolyplocoid nor palmate ribs occur but some polyplocoid-like rib occurs in the outer whorl preserved. Some of the specimens illustrated by Geyer (1961) have more or less common, shallow to deeper, large constrictions, and a more or less irregular ribbing in which polyplocoid ribs could be better represented than subpolyplocoid ribs (e.g., Geyer, 1961, pl. 12, fig. 5). Moreover, in the specimens illustrated by Geyer (1961, pl. 12, figs. 6 and 7) there are traces of incipient to accentuate weakening or smoothing of the sculpture towards the mid-flank, respectively. All these specimens were reinterpreted as Atax. (Schneidia) lussasense by Atrops (1982, p. 177-181) based on the comparison with ataxioceratins collected bed-by-bed in SE France, but this author included a wrong citation of their illustrations in the synonymy list. Both the coiling degree and the ribs' crowding in the Geyer's types place within the range shown in Figure 4 for Schneidia lussasense Atrops. Morphological similarity is closer with specimens showing coiling degrees between average and extremely high U/D values, and ribs' crowding between average and slightly lower values.

Selected "species" of genus Ataxioceras erected by Schneid. Among types described in pioneer monographies, Schneid's "species" of 


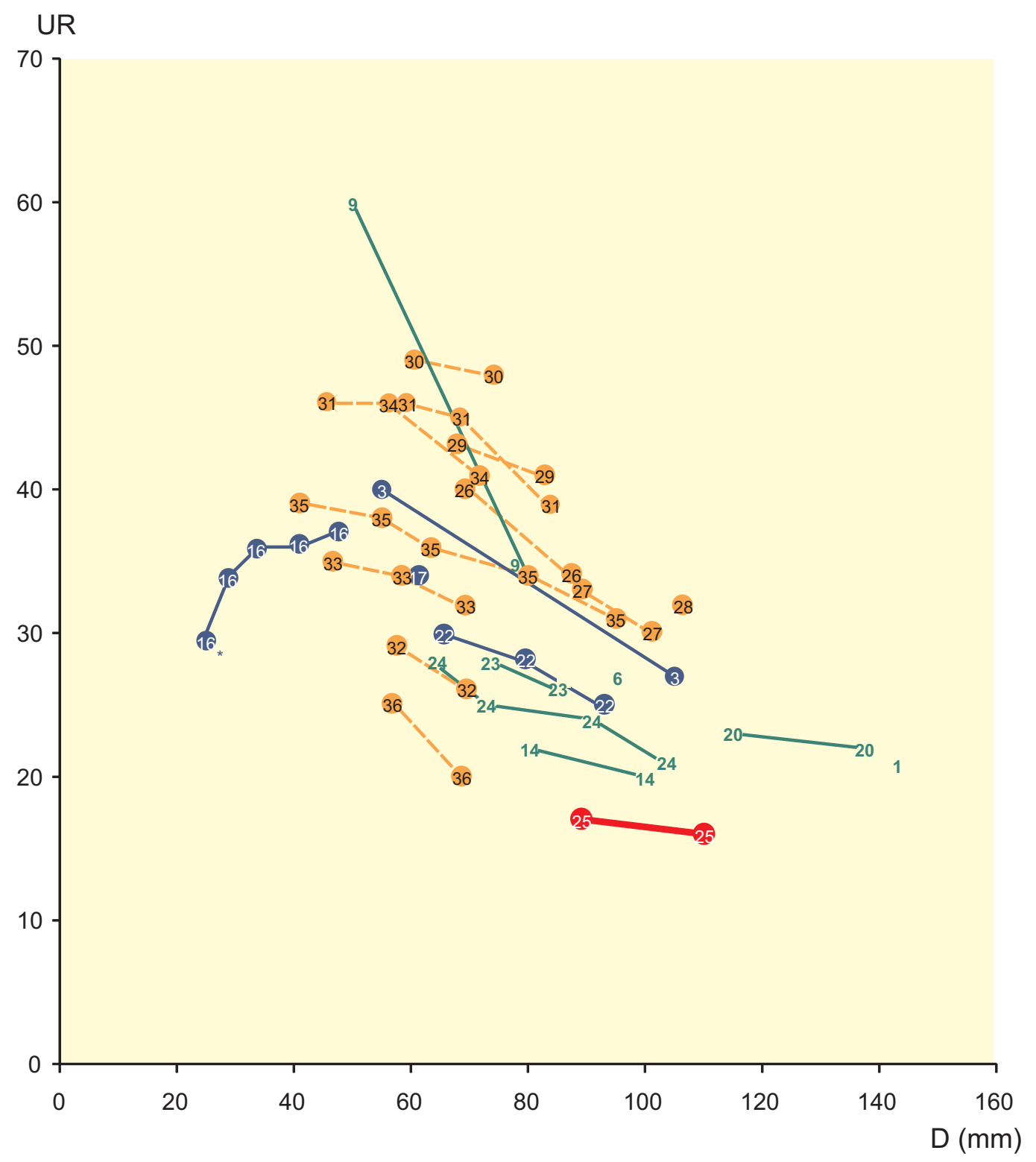

$$
\begin{aligned}
& 1 \text { Atax. barbatum Schneid, 1944, pl. 10, fig. } 1 \\
& 3 \text { Atax. didymoides Schneid, 1944, pl. 5, fig. } 11 \\
& 6 \text { Atax. pulchellum Schneid, 1944, pl. } 11 \text { fig } 7 \\
& 9 \text { Atax. semistriatum Schneid, 1944, pl.1, fig. } 9 \\
& 14 \text { Atax. validum Schneid, 1944, pl. 11, fig. } 5 \\
& 16 * \text { A. (A.) guentheri in Geyer, 1961, pl. 1, fig. } 5 \\
& 17 \text { A. (A.) guentheri in Geyer, 1961, pl. 12, fig. } 5 \\
& 20 \text { A. (A.) involutum in Geyer, 1961, pl. 6, fig. } 5 \\
& 22 \text { A. (A.) subinvolutum in Geyer, 1961, pl. 10, fig } 6 \\
& 23 \text { A. (A.) subinvolutum in Geyer, 1961, pl. 12, fig. } 1 \\
& 24 \text { A. (A.) subinvolutum in Geyer, 1961, pl. 12, fig. } 2
\end{aligned}
$$

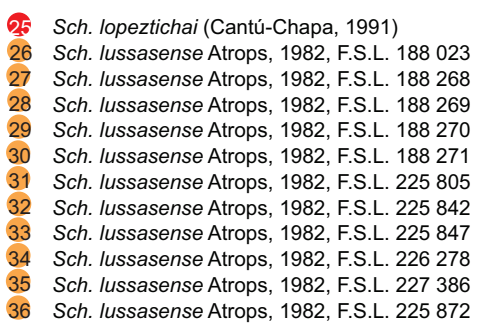

FIGURE 3. Bivariate plot of ribbing curves for Schneidia lussasense (Atrops, 1982), Schneidia lopeztichai (CantúChapa, 1991) and involute "species" assigned to genus Ataxioceras by Wegele (1929), Schneid (1944), and Geyer (1961). Mainly phragmocones of nominal "species" of Ataxioceras, revised or not after their original interpretation (green). Taxa synonymous of Schneidia lussasense according to Atrops, 1982 (blue). Schneidia lopeztichai (CantúChapa) (red). Schneidia lussasense from SE France in Atrops, 1982 (orange). Note less number of nominal species than in Figure 4 because of unidentified precise data about shell diameter. Dubious interpretation for small specimen below $40-50 \mathrm{~mm}\left({ }^{*}\right)$. See text for comparative analyses. 
genus Ataxioceras such as semistriatum, didymoides and tentaculatum in Schneid (1944) also correspond to shells with relatively involute coiling, and sculpture more or less comparable to that observed in Atax. (Atax.) lopeztichae CantúChapa.

Atax. semistriatum and Atax. aff. semistriatum in Schneid (1944, pl. 1, fig. 11; pl. 1, fig. 12), show calculated U/D $27 \%$ and U/H 0.62, and U/D 25$30 \%$ and $\mathrm{U} / \mathrm{H} 0.86$, respectively. These values contrast with the single value of U/D $22.5 \%$ obtained from data given by Schneid (1944). These specimens are more evolute and crowded ribbed than the type described by Cantú-Chapa (1991), without development of real polyplocoid ribs. Atax. semistriatum in Schneid (1944, pl. 1, fig. 10), showing calculated U/D 22-25\% and U/H 0.48-0.50, has a coiling degree comparable to that obtained from the original illustration of Atax. (Atax.) lopeztichae Cantú-Chapa, ranging from similar to slightly higher values than those reported by Cantú-Chapa (1991, p. 18: U/D 22\%). However, the whorl height is higher, and developed much more crowded, fine ribbing in which some irregular "divisions" and narrow constrictions occur on the outer whorl preserved. All these specimens of Atax. semistriatum Schneid were interpreted as Atax. (Schneidia) lussasense by Atrops (1982). Their coiling degrees range throughout those shown for Schneidia lussasense Atrops in Figure 4, while the ribs' crowding extends between values lower to slightly above the average for this species.

Ataxioceras didymoides Schneid (1944, pl. 5, fig. 11) shows irregular, comparable rib "divisions" but it is clearly more evolute (calculated U/D 2831\%; data in Schneid, 1944 indicate U/D 38\% for the specimen he illustrated in pl.5, fig. 10), and developed large, shallow constrictions. The coiling degree corresponds to evolute variants of Schneidia lussasense Atrops here (Figure 4), while the ribs' crowding places well centred to slightly below average values within the range shown in Figure 4.

In Ataxioceras tentaculatum Schneid (1944, pl. 12, fig 3), the calculated coiling degree (U/D 30$31 \%$ ) is within the range obtained from data given by Schneid (1944) revealing a clearly more evolute shell than it is in the Cantú-Chapa's type. The irregular ribbing shows some rib "divisions" which are comparable to those observed in Atax. (Atax.) lopeztichae Cantú-Chapa, but the sculpture in Atax. tentaculatum Schneid is sharper and stiffer, with more crowded primary ribs. Both the coiling degree and the ribs' crowding in Atax. tentaculatum Schneid correspond to evolute and slightly less than average crowded ribbed variants of Schneidia lussasense Atrops in Figure 4.

All these three "species" erected by Schneid (1944) were also reinterpreted as Atax. (Schneidia) lussasense by Atrops (1982), based on the comparison with ataxioceratins collected bed-by-bed in SE France.

Schlegelmich (1994) provided a valuable reillustration of old types of ataxioceratins, among other Jurassic ammonites collected from southern Germany. As could be expected for such a large revision, this author rather restricted his interpretations to morphology, without paying special attention to the incidence of homeomorphism in ammonite taxonomy and systematics. Hence, the mere occurrence of polyplocoid ribs determined his interpretation of genus Ataxioceras. Schlegelmich (1994) included all microconchs of Lower Kimmeridgian ataxioceratins in the subgenus Parataxioceras. Therefore, he did not consider the subgenus Schneidia Atrops, and reported Atax. (Schneidia) lussasense Atrops as Atax. (Parataxioceras) lussasense Atrops.

Some evaluations made by Schlegelmich (1994) on mainly involute specimens interpreted as Ataxioceras by Schneid (1944) and Geyer (1961) are of interest for the case under study. Thus, Ataxioceras pulchellum Schneid was interpreted by Schlegelmich (1994) with lesser variability than it was envisaged by Geyer (1961). Schlegelmich (1994) excluded constricted variants (e.g., Geyer, 1961, pl. 11, fig. $6=$ Atax. [Schneidia] lussasense in Atrops, 1982) and his interpretation resulted more in accordance with the types illustrated by Schneid (1944, pl. 11, figs. 7-8). The illustrations provided by Schneid (1944) show two phragmocones with a more crowded ribbing than it is in Atax. (Atax.) lopeztichae Cantú-Chapa. According to data in Schneid $(1944$, p. 37$)$, the shell size is similar to that in Atax. (Atax.) lopeztichae CantúChapa, as well as the coiling degree (23\% according to Schneid, 1944 , but $23-26 \%$ obtained from his illustration). Moreover, the ribbing pattern includes some rib structuring very similar to that shown in the Cantú-Chapa's species, including the weakening or smoothing below the mid-flank. The two phragmocones illustrated by Schneid (1944) are placed among the more tightly coiled variants, with crowded ribs slightly low than average, within the range shown in Figure 4 for Schneidia lussasense Atrops. They most probably represent macroconchs and cannot be conclusively interpreted as belonging to Ataxioceras or Schneidia. The specimen of Ataxioceras pulchellum illustrated by Geyer 


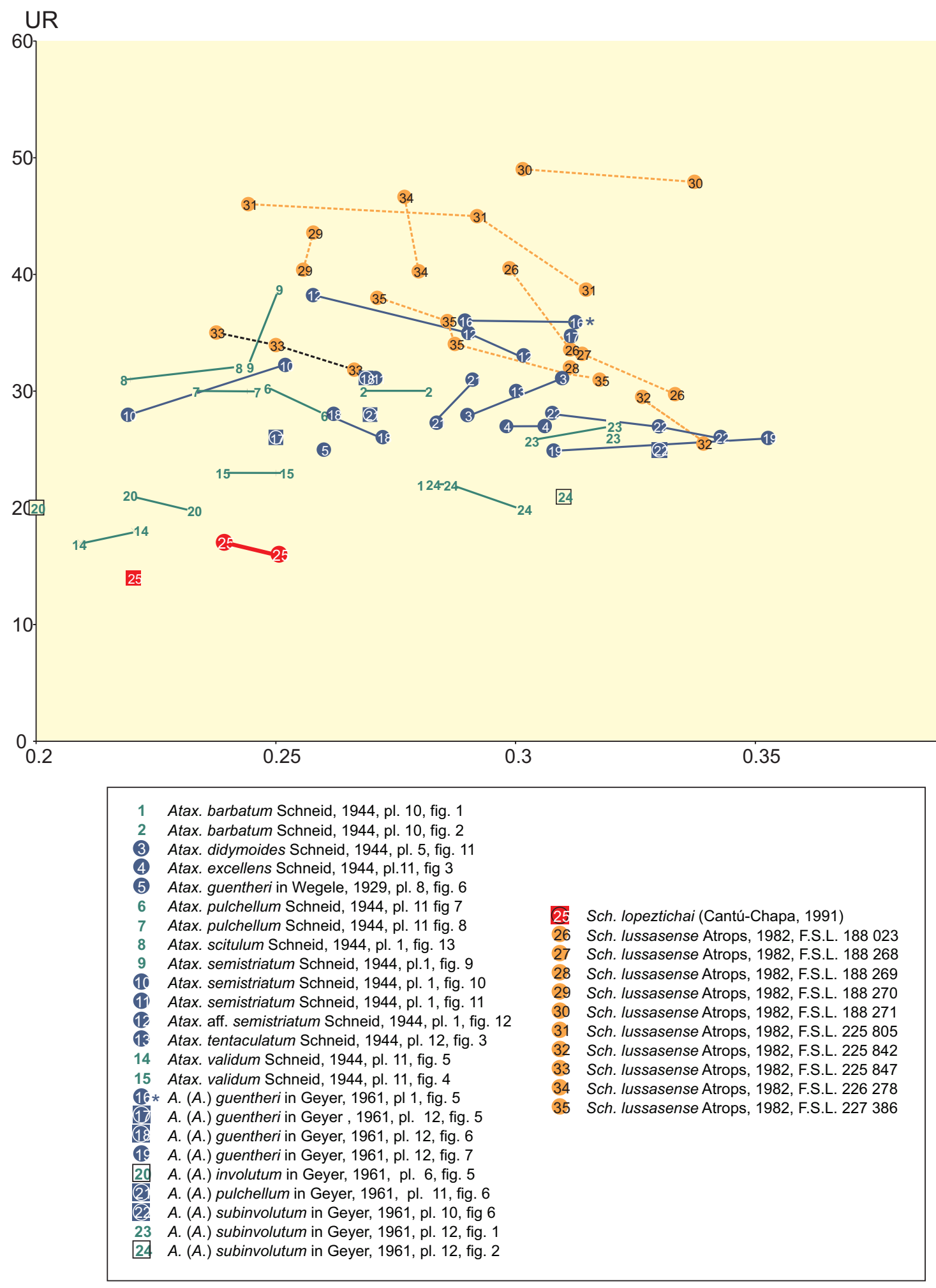

FIGURE 4. Bivariate plot of primary ribs' crowding vs. coiling degree for Schneidia lussasense (Atrops, 1982; ammonite species in his synonymy list included), Schneidia lopeztichai (Cantú-Chapa, 1991), and involute "species" assigned to genus Ataxioceras by Wegele (1929), Schneid (1944), and Geyer (1961). Colours and asterisk as in Figure 3. Original measurements separated up to $3 \%-5 \%$ from those obtained from the illustrations of the specimens referred (squares). See text for comparative analyses. 
(1961, pl. 11, fig. 6) was considered synonymous of Atax. (Schneidia) lussasense by Atrops (1982), and is well placed within the range for specimens of Schneidia lussasense Atrops with relatively averaged values of coiling and lesser crowded ribs, as it is shown in Figure 4.

Schlegelmich (1994) considered Atax. scitulum Schneid, Atax. validum Schneid, Atax. barbatum Schneid, and Atax. (Atax.) involutum Geyer to be interrelated species.

In Ataxioceras scitulum Schneid (1944, p. 8, pl. 1, fig.13), the author gave a single series of measurements indicating D $82 \mathrm{~mm}, \mathrm{U} 21.9 \%, \mathrm{U} / \mathrm{H}$ 0.473 , W/H $0.657, \mathrm{H} 46.3 \%$, W $30.4 \%$. The specimen illustrated could be easily interpreted as an involute Schneidia (U/D 23-24\% according to data obtained from Schneid's illustration). In accordance with the data in Schneid (op. cit), scitulum has a slightly smaller and wider shell than Atax. (Atax.) lopeztichae Cantú-Chapa, and shows a similar coiling degree. Its ribbing is much crowded, without relevant weakening or smoothing of the mid-flank sculpture, except for the outermost one-fourth of the outer whorl preserved. Noteworthy, on the outer whorl is the occurrence of subpolyplocoid to irregular and fasciculate-palmate-like ribs slightly reinforced on the umbilical edge. The better preserved phragmocone illustrated by Schneid is placed within the range of specimens with tighter coiling and average rib's crowding shown in Figure 4 for Schneidia lussasense Atrops, but incomplete preservation precludes its conclusive interpretation as belonging to Ataxioceras or Schneidia.

In Ataxioceras validum Schneid (1944, p. 36, pl. 11, fig. 4-6), the author gave two series of measurements indicating $D 113 \mathrm{~mm}, \mathrm{U}(21.2 \%), \mathrm{U} / \mathrm{H}$ (0.452), W/H (0.603), H (46.9\%), W (28.3\%); and D $102 \mathrm{~mm}, \mathrm{U}(18.6 \%), \mathrm{U} / \mathrm{H}(0.475), \mathrm{W} / \mathrm{H}(0.8), \mathrm{H}$ $(39.2 \%), W(31.3 \%)$. The three illustrated phragmocones agree with rather involute Schneidia-like shells, especially the smaller one. Their sculpture shows subpolyplocoid ribs on the outer whorls, and rib weakening or smoothing with more or less realized fasciculate-palmate-like structures on the last whorl preserved. No typical polyplocoid ribs seem to be developed. These specimens correspond to shells, slightly more involute and with slightly wider flanks than shown in Atax. (Atax.) lopeztichae Cantú-Chapa. However, the coiling degrees obtained from Schneid's and Cantú-Chapa's illustrations could be closer (U/D 21\%-24\%). The flanks in the phragmocones slightly larger than 100 $\mathrm{mm}$ (Schneid, 1944, pl. 11, figs. 4-5 = macroconchs of Schneidia or Ataxioceras?) are slightly higher than they are in the Cantú-Chapa's type, the ribs' crowding is similar to slightly higher, and their primary ribs are shorter and reinforced on the outer whorl preserved.

In Ataxioceras barbatum Schneid (1944, p. 37 , pl. 10, fig. 1-2), the author gave three series of measurements. These indicate D $165 \mathrm{~mm}, U$ (24.2\%), U/H (0.588), W/H (0.632), H (41.2\%), W (26\%); D $143 \mathrm{~mm}, \mathrm{U}(22.3 \%), \mathrm{U} / \mathrm{H}(0.533), \mathrm{W} / \mathrm{H}$ (0.583), H (41.9\%), W (24.4\%); and D $75 \mathrm{~mm}, \mathrm{U}$ (21.3\%), U/H (0.457), W/H (0.571), H (46.6\%), W $(26.6 \%)$. The coiling degree obtained from Schneid's illustrations ranges from 25 to $28 \%$. The two illustrated specimens show sculpture weakening (smoothing?) increased with shell size, a trait which is accentuated in the greater one (phragmocone). The smaller specimen (Schneid, 1944, pl. 10, fig.2) corresponds to a juvenile of Schneidia with well-developed constrictions, as indicated by its morphological similarity with the specimen of Atax. tentaculatum illustrated by Schneid (1944, pl. 12, fig. 3), which was reinterpreted as Atax. (Schneidia) lussasense by Atrops (1982; but written as tentaculum by this author). According to measurements in Schneid (1944), the "species" barbatum could reach shell sizes greater than Atax. (Atax.) lopeztichae Cantú-Chapa, but would realize similar coiling degrees and whorl sections with flanks of comparable height in shells sizes between $75 \mathrm{~mm}$ and $143 \mathrm{~mm}$. Concerning the style of ribbing, descriptions in Schneid (1944, p. 38) point to fasciculate-palmate-like ribs. The small specimen illustrated by Schneid (1944, pl. 10, fig. 2) shows a coiling degree of $26-28 \%$ and only the irregular ribbing that usually anticipates later ribs' complexity at greater shell size. The greater one (Schneid, 1944, pl. 10, fig. 1; Schneidia macroconch or incomplete Ataxioceras?) shows an eroded flank with preservation of peripheral ribs, a single, relatively shallow constriction with prominent adapertural margin, and short primary ribs reinforced on the umbilical edge. As well as other specimens of Schneid's "species" interpreted as belonging to Ataxioceras, coiling and ribs' crowding in the "species" barbatum Schneid agrees with values close to the average within the range shown for Schneidia lussasense Atrops in Figure 4. The "species" barbatum was interpreted by Geyer (1961) as potentially synonymous of Ataxioceras (Atax.) hypselocyclum (Fontannes).

Ataxioceras (Ataxioceras) involutum Geyer (1961, p. 61-62; pl. 6, fig. 5). The author gave a single series of measurements indicating $D 80 \mathrm{~mm}$ and U/D $20 \%$, with a ribbing index of 6.6 at $60 \mathrm{~mm}$ 
and 8 at $80 \mathrm{~mm}$ of shell diameter. Geyer (1961) reported polyplocoid and diversipartite rather than subpolyplocoid ribs. However, data from his illustration indicate a slightly looser coiling (22-23.5\%) and the polyplocoid-like ribs identifiable on the phragmocone (i.e., at the rear half of the outer whorl in Geyer, 1961, pl. 6, fig. 5) show primaries shorter than they are in typical polyplocoid ribs. The latter is more evident on the body chamber where fasciculate-palmate-like ribs seems to be missing due to subtle weakening or smoothing of the sculpture on the mid-flank. Geyer (1961) recognized the above commented Atax. guentheri (Oppel) and Atax. pulchellum Schneid as related forms, which were interpreted as Atax. (Schneidia) lussasense by Atrops (1982). According to the ribbing pattern depicted by Geyer (1961, p. 64), the irregularity of the sculpture in Atax. (Atax.) involutum is similar to that in Atax. (Atax.) lopeztichae Cantú-Chapa before the prevalence of fasciculatepalmate ribs in the adoral half of the incomplete outer whorl of the former. According to data in Geyer (1961), Atax. (Atax.) involutum n. sp. (U/D $20 \%$ ) realized a coiling degree tighter than was originally described for Atax. (Atax.) lopeztichae Cantú-Chapa (U/D 22\%), but the difference in the preserved shell diameters makes this datum something inconclusive. The limited weakening of the sculpture close to the mid flank in Atax. (Atax.) involutum Geyer could relate to the combination of its relative smaller shell size (unfinished growth?) as well as to the incompleteness of the preserved shell in the single specimen described up to date. The primary ribs in Atax. (Atax.) involutum Geyer are slightly more crowded and more delicately reinforced than they are in Atax. (Atax.) lopeztichae Cantú-Chapa. Atax. (Atax.) involutum Geyer places closely below the lowermost range of coiling and ribs' crowding of Schneidia lussasense Atrops (Figure 4). The species erected by Geyer (1961) most probably represents a microconchiate Schneidia rather than Ataxioceras, but the absence of peristome impedes a conclusive interpretation.

Ataxioceras (Ataxioceras) subinvolutum (Siemiradzki) was illustrated by Geyer (1961, p. 56-57; pl. 10, fig. 6, pl. 12, figs. 1 and 2). This author gave a series of measurements indicating coiling degrees of and 30\%-33\% for shell diameters between 92 and $110 \mathrm{~mm}$, and 30\%-39\% from shells greater than $120 \mathrm{~mm}$. Thus, the specimens measured by Geyer (1961) indicate more evolute shells at shell sizes equivalent to that mentioned by Cantú-Chapa (1991) for his Ataxioceras (Atax.) lopeztichae. Geyer (1961, p. 56) emphasized a regular, strong, polyplocoid ribbing, an observation which agrees with the ribbing pattern he depicted in his fig. 71. This author also noted the occurrence of some constrictions, but he did not made comparisons with any other species of Ataxioceras he studied. As previously stated, Atrops (1982, p. 177) reinterpreted the specimen illustrated by Geyer (1961, pl. 10, fig. 6) as Atax. (Schneidia) lussasense, while the specimens illustrated by Geyer (1961, pl. 12, figs. 1 and 2) were reinterpreted as Atax. (Atax.) hypselocyclum hypselocyclum (Fontannes), with some doubts (Atrops, 1982, p. 254). The large phragmocones illustrated by Geyer (1961, pl. 12, figs. 1 and 2) most probably represent macroconchiate specimens, which agrees with the interpretation made by Atrops, who considered Atax. (Atax.) hypselocyclum hypselocyclum (Fontannes) as a macroconch from the Lower Kimmeridgian, Hypselocyclum Zone. Unfortunately, Atrops (1982) did not give more precise comments about the status of Atax. (Atax.) subinvolutum (Siemiradzki) after his revision. Schlegelmich (1994, p. 80) interpreted Atax. (Atax.) subinvolutum (Siemiradzki) as close to Atax. prominens Schneid (1944, pl. 2, figs. 5 and 6), which is a species rarely cited and not analyzed by Schlegelmich (1994). On the basis of the information available, Atax. (Atax.) subinvolutum (Siemiradzki) is not conclusively known, and while the specimen illustrated by Geyer (1961, pl. 10, fig. 6) can be interpreted as Schneidia, the two phragmocones illustrated in Geyer (1961, pl. 12, figs. 1 and 2) only can be interpreted as macroconchs without any precise assignation at the genus level.

\section{Remarks on morphologically similar Lower Kimmeridgian ataxioceratinae collected bed- by-bed in southern Europe, with indication of intra-biozone level biostratigraphy.}

Atrops (1982) erected and illustrated a new microconchiate subgenus, Ataxioceras (Schneidia), based on bed-by-bed sampling of the uppermost Platynota and lowermost Hypselocyclum zones in SE France. This author interpreted dimorphism at the subgenus level being the subgenera Schneidia and Parataxioceras the microconchs of his subgenus Ataxioceras s. str., which was interpreted as the corresponding macroconch (Atrops, 1982, p. 263). Moreover, Atrops (1982) recognized that "Ces sous-genres liés au dimorphisme n'ont pas la même valeur que les sousgenres phylogénétiques» (Atrops, 1982, p. 43). Typically, his new subgenus Ataxioceras (Schneidia) shows wide and short lappets (Figure 


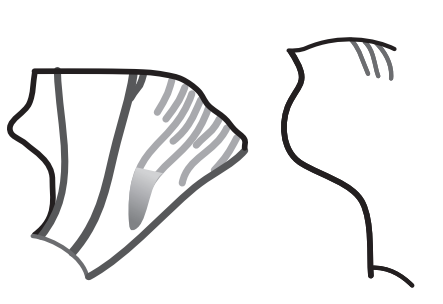

1

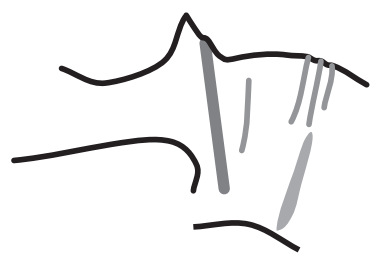

6

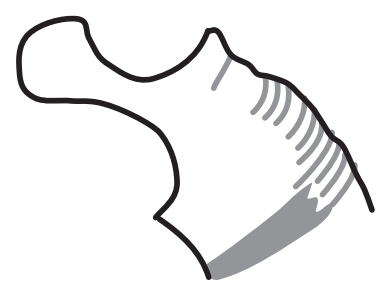

10

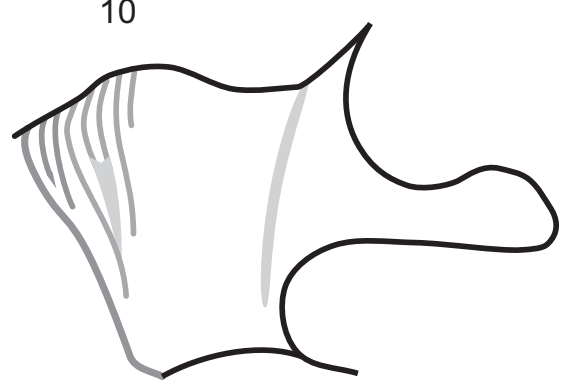

13

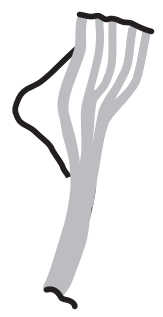

3

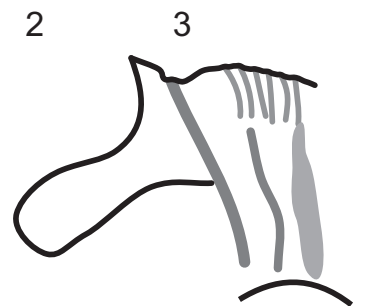

7

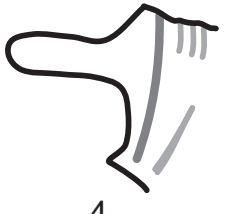

4
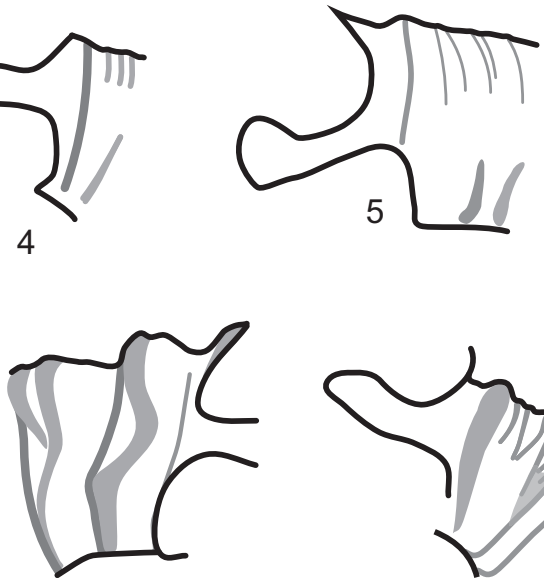

8

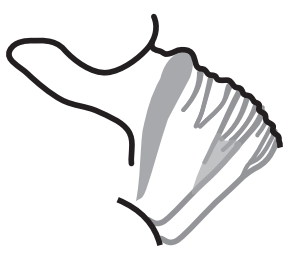

9

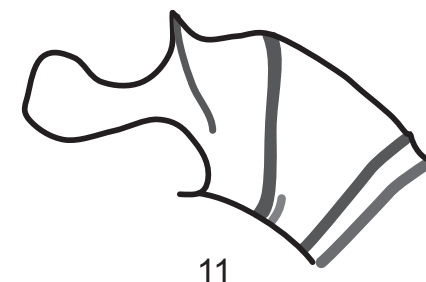

11

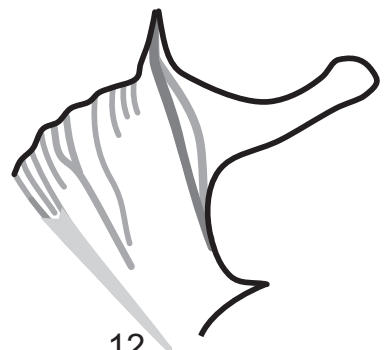

12

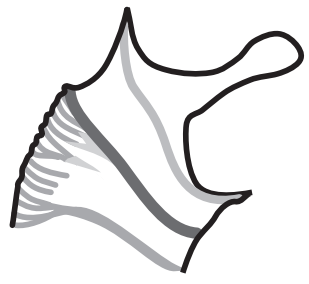

14

FIGURE 5. Adapertural structures in microconchiate Schneidia, Ataxioceras and Parataxioceras drafted from different authors as indicated: 1 - Schneidia lussasense Atrops (= Ataxioceras [Atax.] subinvolutum [Siemiradzki] in Geyer, 1961, pl 10, fig. 6). 2 - Schneidia lussasense (= Atax. [Schn.] lussasense in Atrops, 1982, pl. 21, fig. 6). 3 - Schneidia lopeztichai (=Atax. [Atax.] lopeztichae in Cantú-Chapa, 1991, fig. 2). 4 - Atax. lothari (Oppel) morphotype lothari Oppel [m] (Moliner, 2009, fig. 2.5 d). 5 - Atax. (Parataxioceras) hyppolytense (Atrops, 1982, pl. 7, fig. 7). 6 - Atax. (Paratax.) hyppolytense (Atrops, 1982, pl. 8, fig. 6). 7 - Atax. (Paratax.) lothari lothari (Oppel) (Atrops, 1982, pl. 42, fig.4). 8 - Atax. (Paratax.) pseudolothari ( Geyer, 1961, pl. 16, fig. 6). 9 - Atax. (Paratax.) evolutum (Atrops, 1982, pl.4, fig. 5). 10 - Atax. (Paratax.) planulatum (Quenstedt) (Geyer, 1961, pl. 14, fig. 2). 11 - Atax. (Paratax.) planulatum (Quenstedt) (Atrops, 1982, pl. 43, fig. 6). 12 - Atax. (Paratax.) oppeli (Geyer, 1961, pl. 16, fig. 5). 13 - Atax. (Paratax.) oppeli (Geyer, 1961, pl. 14, fig. 2). 14 - Atax. (Paratax.) pseudoeffrenatum Wegele (Geyer, 1961, pl. 16, fig. 1).

5.1-3). In the youngest species Ataxioceras (Schneidia) lussasense recorded from the lowermost Hypselocyclum Zone, Atrops (1982) clearly separated two phenotype groupings showing more crowded, fine ribbing and less crowded and stronger ribbing, respectively. In contrast, these morphological groupings based on ribbing features seem to have no direct, close relationship with coiling (e.g., Atrops, 1982, pl. 21, figs. 1 and 3), which ranges from $26 \%$ to $34 \%$ and $37 \%$, respectively in these specimens collected in SE France. Hence, Atrops (1982, p. 181) envisaged a large intra-spe- 
cies, phenotype variability for his Atax. (Schneidia) lussasense. Except for differences in the peristome and the shell size, the more evolute variants of the microconchiate, lappeted Atax. (Schneidia) lussasense Atrops could be difficult to separate from some macroconchs of ataxioceratins of a slightly older, or even of the same, age (e.g., Atax. [Atax.] striatellum Schneid in Atrops, 1982, which is restricted to the uppermost Platynota Zone, but its relatives are found also in the lower part of the Hypselocyclum Zone; cf. Atrops, 1982, p. 232). In addition, the involute variants would be difficult to separate from smaller shells of the younger macroconch Atax. (Atax.) hypselocyclum semistriatum (Schneid) (in Atrops, 1982, which is restricted to the upper part of the Hypselocyclum Zone = Ataxioceras lothari Oppel chrono-morphotype semistriatum Schneid [M] in Moliner, 2009). Older and more typical species of Atax. (Schneidia), collected from the upper part of the Platynota Zone in SE France, clearly separate from the Atax. (Atax.) lopeztichae Cantú-Chapa in shell morphology and sculpture, but show the same type of lappets (Figure 5.3). As shown in Figure 4, specimens of Atax. (Schneidia) lussasense collected from southern France by Atrops (1982) were more crowded ribbed than the old "species" this author interpreted as synonymous and collected from more inland seas corresponding to northern and middle Franconia, Swabia and northern Switzerland (Wegele, 1929; Schneid, 1944; Geyer, 1961). Site effects expressed in terms of reaction norms could be responsible for such a phenotype difference.

Moliner (2009) investigated Lower Kimmeridgian ataxioceratins in the eastern Iberian Chain or Range (NE Spain) based on a bed-by-bed sampling, and provided precise data from a large collection including Schneidia, the new subgenus erected by Atrops (1982) just commented. In the revision of the ataxioceratin taxa made by Moliner (2009), this author re-interpreted Schneidia at the genus level. This author favoured palaeobiological coherence in his interpretations at the species level joining dimorphic couples (micro- and macroconchs) within each given nominal species. Hence, Moliner (2009) reported the occurrence of Schneidia Atrops (emend. Moliner, 2009), and identified dimorphs (macro- and microconchs) joined in the corresponding nominal species and genus. This author confirmed the occurrence of rather wide but short lappets as being the typical peristome for microconch specimens of Schneidia Atrops (emend. Moliner, 2009), as first noted by Atrops (1982) for the French material he studied. Since
Atrops (1982) reported the occurrence of specimens with simple adoral margins within his grouping of Atax. (Schneidia) lussasense showing irregular ribbing (Atrops, 1982, p. 180, pl. 33, fig. 3 ), the possibility exists for the occurrence of micro- and macroconchs within the material interpreted as Ataxioceras (Schneidia) lussasense by Atrops (1982). Whatever the case, Schneidia lussasense Atrops seems to be missing in the eastern Iberian Chain according to Moliner (2009). As well as reported by Atrops for SE France, the ataxioceratins collected bed-by-bed by Moliner (2009) from the Platynota and Lothari (= Hypselocyclum) zones in the eastern Iberian Chain demonstrated the occurrence of homeomorphism at both the genus and species levels. In addition, Moliner (2009) identified phenotype deviations with respect to species identified in SE France, and cases of endemism in the material he analyzed from another epicontinental but comparatively more inland sea that it presumably was northwards in southern France.

In the case of Schneidia Atrops (emend. Moliner, 2009), a microconch with wide but short lappets (Figure 5.1-2), the differential interpretation of dimorphism favoured by Atrops (1982) and Moliner (2009) can be summarized as follows: (i) Atrops (1982, p. 263) proposed the corresponding macroconch in the subgenus Ataxioceras (Ataxioceras), which shows simple peristome and would have another complementary microconchiate counterpart in his subgenus Ataxioceras (Parataxioceras) with long, spatulate lappets (Figure 5.5-14); and (ii) Moliner (2009, p. 168) interpreted Schneidia as a separate genus in which he identified the wide but short lappets, and the macroconchs counterparts in those specimens of this genus that showed simple adoral margins. The interpretation proposed by Moliner (2009) confirms statements made by Atrops (1982) "... de penser qu'il existe des "espèces biologiques" plus vastes que celles que nous avons reconnues" (Atrops, 1982, p. 41), and "... à une époque ou la tendance est au regroupement des dimorphes au sein d'une même espèce" (Atrops, 1982, p. 263), and reinforces the updated trend towards the option for approaching more palaeobiologically grounded interpretations.

According to Moliner (2009), Ataxioceras microconchs collected from the eastern Iberian Chain show relatively long, narrow lappets, which contrast with the rather wide and short lappets which are typical in Schneidia microconchs (Figure 5.1-4). 


\section{REMARKS ON SYSTEMATICS AND BIO- CHRONOSTRATIGRAPHY}

On the basis of the information available, the following combination of features in microconchs supports the genus level separation of Schneidia and Ataxioceras: (1) different adapertural structures (short, wide lappets are typical in Schneidia vs. longer and narrow ones characterize Ataxioceras); (2) differential origin for subpolyplocoid and the less common polyplocoid-like ribs (complex rib connections-"divisions"-related to crowded ribbing in Schneidia vs. typical polyplocoid ribs unrelated to ribs' crowding in Ataxioceras); and (3) different course for primary ribs towards the aperture on the outermost whorl (i.e., variable, progressive lengthening of primary ribs in Schneidia vs. the opposite trend in Ataxioceras).

In accordance, and taken into account the combination of ribbing pattern and peristome Ataxioceras (Ataxioceras) lopeztichae Cantú-Chapa is here reinterpreted as belonging to genus Schneidia. Following nomenclatural rules for species names in the ICZN article 31.1.2, the species name is changed to lopeztichai.

As commented above, no precise stratigraphic datum was available to Cantú-Chapa (1991) for the single, isolate specimen he studied, which is here reinterpreted as Schneidia lopeztichai (Cantú-Chapa). In addition, no species of perisphinctoids were reported by Burckhardt (1930, $p$. 91) when mentioned "Sutneria (groupe de S. platynota Rein.)" from the "barranca du Rio Vinasco" in Huyacocotla, Veracruz, E Mexico, and the authors failed to record Sutneria from levels containing Schneidia in Mexico (Villaseñor et al., 2000, 2012; 2015). Also of interest is the well-known fact that the record of Sutneria platynota (Reinecke) varies regionally, diminishing towards the top of the Platynota Zone in NE Spain (Moliner, 2009; Moliner and Olóriz, 2009) and southern Germany (Ziegler, 1983; Schairer, 2000; Schick, 2000), but seems to show a reversal trend in SE France (Atrops, 1982) and NE Switzerland (Moor, 2009). It is clear that sedimentological and ecostratigraphic analyses are necessary before a conclusive interpretation is reached about differences in local/regional biostratigraphic ranges. However, this information is not available at present and could only be obtained through developing a specific research program throughout these European regions. Taking into account all the available information, we envisage the possibility for rare records, if any, of Sutneria platynota (Reinecke) in the upper-to-uppermost part of the stratigraphic interval corresponding to the Platynota Zone in Mexico, which could correspond with unfavourable conditions for ammonites, at least in north-central Mexico where ammonite records are rare. In addition, and on the basis of the comparative analysis made of Schneidia lopeztichai (Cantú-Chapa), we interpret that the specimen reported by Cantú-Chapa (1991) from southern Mexico (Oaxaca) presumably indicates stratigraphic horizons corresponding to the uppermost Platynota Zone or, most probably, to the lowermost part of the Hypselocyclum Zone in the Secondary Standard Scale for Kimmeridgian biochronostratigraphy in Europe. Although the possibility has been assumed for the local variation in the registered last occurrence of the Schneidia Assemblage in Mexico (e.g., Villaseñor et al., 2015), new ammonite records based on bed-bybed sampling are necessary before a conclusive age-interpretation can be made about the precise biostratigraphic range of Schneidia lopeztichai (Cantú-Chapa).

\section{PALAEOBIOGEOGRAPHIC REMARKS}

Palaeobiogeographic interpretations of Late Jurassic ammonites from Mexico have been largely reported since Burckhardt's times, with variable preference for a Panthalassian or a westTethyan provenance for colonizers (compare Cantú-Chapa, 1991 and Olóriz et al., 1990), but some proposals envisaging Mexican seas as dispersal centres were also made (e.g., Arkell, 1956; Jeletzky, 1984). Oxfordian perisphinctoids of Cuban and Tethyan affinity are exclusively known from SE Mexico (López-Palomino et al., 2006; Villaseñor et al., 2012; and research in progress). According to previous interpretations made by the authors on Late Jurassic ammonites from Mexico and related occurrences of Tethyan forms (Olóriz, 1987, 1992; Olóriz et al., 1990, 2000, 2010; Olóriz and Villaseñor, 1999, 2006; Villaseñor and Olóriz, 2004, 2010; Villaseñor et al., 2002, 2003, 2004, 2011), the first occurrence of ataxioceratins ammonites above Zuloaga carbonates and lateral equivalents in Mexican areas would be linked to transgressive effects related to the drowning of the Zuloaga shelf-system early during Kimmeridgian times. This drowning was most probably forced by regional, geodynamic events of plate readjustment resulting in major depositional and palaeoenvironmental changes affecting north-central Mexico, the northern rim of the Gulf of Mexico Basin and related Caribbean areas (e.g., Olóriz et al., 2003; Cobiella and Olóriz, 2010; and references therein). In the resulting new palaeoenvironmental scenario 
forced by block tectonics and tectono-eustatic interactions, source areas for ataxioceratinsTethyan derived colonizers-would be the outermost sectors of shelves connecting epioceanic seaways between the north- and south-American plates with the Hispanic Corridor. As demonstrated by the authors (Olóriz, 1992; Olóriz and Villaseñor, 1999; Olóriz et al., 1990, 2000; Villaseñor et al., 2003, 2011), colonization of epicontinental, inland seas on Mexican areas promoted phenotype deviations and endemism in Late Jurassic ammonites, among which Schneidia lopeztichai (Cantú-Chapa) represents another example.

In addition, no records of true Ataxioceras are known from outcrops belonging to palaeomargins included neither in the surroundings of the presentday Pacific Ocean nor in India since they are distinct homeomorphs of inconclusively known and variable age (Villaseñor et al., 2014, 2015). Based on the palaeogeographic and palaeobiogeographic information available, to envisage an eastern Panthalassian-i.e., "palaeo-Pacific"-origin for explaining the occurrence of the Lower Kimmeridgian ataxioceratin ammonites investigated in Mexico (e.g., Cantú-Chapa, 1991; Villaseñor et al., 2015 and references therein) is highly hypothetical and therefore this hypothesis is disfavoured against the alternative one (see above) based on the known cases of colonization events via the Hispanic Corridor.

\section{CONCLUDING REMARKS}

Taken into account the information available, the ammonite taxon Ataxioceras (Ataxioceras) lopeztichae, erected by Cantú-Chapa (1991), is reinterpret as Schneidia lopeztichai (Cantú-Chapa) based on: (1) the lack of well-developed real polyplocoid ribs; (2) the occurrence of irregular, obscure rib-connections ("divisions") in Schneidia (e.g., Atax. [Schn.] aff. elmii and Atax. [Schn.] lussasense in Atrops, 1982); (3) the limited occurrence of polyplocoid ribs in Schneidia Atrops; (4) the occurrence of a similar, high ribbing index at equivalent shell diameters in the youngest populations of genus Schneidia (e.g., 7.5 in lussasense, Atrops, 1982, and 7.1 in lopeztichae CantúChapa-recte lopeztichai); (5) the occurrence of Schneidia-type lappets in the species lopeztichae Cantú-Chapa (recte lopeztichai); (6) the very rare, even dubious, record of potential Ataxioceras between the top of the Zuloaga carbonates, and lateral equivalents, and the first occurrence of genus Idoceras in the sections investigated in Mexico; and (7) the precise biochronostratigraphic range interpreted for Schneidia lopeztichai (CantúChapa), which cannot be conclusive given the single, isolate specimen known up to date and the limitations related to lacking information about associated ammonites in Mexico.

\section{ACKNOWLEDGEMENTS}

The present research was made within the context of Project CGL2012-39835 MINECO, Spain, and the Project PAPIIT IN105311-3, UNAM. Mexico. The authors thanks to the editors of the Revista Mexicana de Ciencias Geológicas for permission to reproduce original illustrations. This contribution benefited from comments and suggestions made by editors and two anonymous reviewers.

\section{REFERENCES}

Arkell, W. J. 1956. Jurassic Geology of the World. Oliver and Boyd Ltd. Edinburgh-London.

Atrops, F. 1982. La sous-Famillie des Ataxioceratinae (Ammonitina) dans le Kimméridgien inférieur de Sud-Est de la France: systématique, évolution, chronostratigraphie des genres Orthosphinctes et Ataxioceras. Documents des Laboratoires de Géologie Lyon, 83:1-463.

Burckhardt, C. 1930. Etude synthétique sur le Mésozoique Mexicain. Mémoire Societé Paléontologique Suisse, 49, 50:1-280.

Cantú-Chapa, A. 1969. Estratigrafía del Jurásico MedioSuperior del subsuelo de Poza Rica, Veracruz (Área de Soledad-Miquetla). Revista del Instituto Mexicano del Petróleo, 1(1):3-9.

Cantú-Chapa, A. 1971. La Serie Huasteca (Jurásico Medio-Superior) del centro este de México. Revista del Instituto Mexicano del Petróleo, 3(2):17-40.

Cantú-Chapa, A. 1979. Bioestratigrafía de la Serie Huasteca (Jurásico Medio y Superior) en el subsuelo de Poza Rica, Veracruz. Revista del Instituto Mexicano del Petróleo, 11:14-24.

Cantú-Chapa, A. 1984. El Jurásico Superior de Tamán, San Luis Potosí, Este de México, p. 207-212. In Perrilliat, M.C. (ed.), Memoria del 3er Congreso Latinoamericano de Paleontología, México, Universidad Nacional Autónoma de México, México.

Cantú-Chapa, A. 1991. Ataxioceras (Ataxioceras) lopeztichae sp. nov., amonoideo del Kimeridgiano inferior de Tlaxiaco, Oaxaca, sur de México. Revista de la Sociedad Mexicana de Paleontología, 4:17-21.

Cantú-Chapa, A. 1992. El Kimeridgiano Inferior del subsuelo en el Este de México. Revista Mexicana del Petróleo, 334:30-35.

Cantú-Chapa, A. 2001. Mexico as the western margin of Pangea based on biogeographic evidence from the Permian to the Lower Jurassic, p. 1-27. In Bartolini, C., Buffler, R.T., and Cantú-Chapa, A. (eds.), The western Gulf of Mexico Basin: Tectonics, sedimen- 
tary basins, and petroleum systems. American Association Petroleum Geologists Memoir, 75, Tulsa.

Cobiella Reguera, J.L. and Olóriz, F. 2010. OxfordianBerriasian Stratigraphy of the North American Paleomargin in Western Cuba: Constraints for the Geological History of the Proto-Caribbean and the Early Gulf of Mexico, p. 421-451. In Bartolini, C. and Román Ramos, J.R. (eds.), Petroleum systems in the southern Gulf of Mexico. American Association Petroleum Geologists Memoir, 90, Tulsa.

Fontannes, F. 1879, Description des Ammonites des calcaires du Château de Crussol, Ardèche (Zone à Oppelia tenuilobata et Waagenia beckeri). Georg, Lyon et Savy, F., Paris édit., 123p.

Geyer, O.F. 1961. Monographie der Perisphinctidae des unteren Unterkimmeridgium (Weisser Jura Y, Badenerschichten) im süddeutschen Jura. Palaeontographica, Abt. A, 117:157 pp.

Hantzpergue, P. 1989. Les Ammonites kimméridgiennes du Haut-Fond d'Europe occidentale. Biochronologie, Systématique, Évolution, Paléobiogéographie. Cahiers de Paléontologie. Éd. du CNRS, Paris.

Jeletzky, J.A. 1984. Jurassic-Cretaceous Boundary Beds of Western and Artic Canada and the problem of the Tithonian-Berriasian stages in the Boreal Realm, p. 177-256. In Westermann, G.E.G. (ed.), Jurassic-Cretaceous Biochronology \& Biogeography of North America. Geological Association of Canada, Special Paper 27, Toronto.

Jiménez-López, J.C. 2011. Sistemática y bioestratigrafía de ammonites del Jurásico Superior de Tamán, San Luís Potosí, México. Unpublished Bachelor Thesis. Facultad de Ciencias, Universidad Nacional Autónoma de México, D. F., Mexico.

López-Caballero, I. 2009. Bioestratigrafía y Tafonomía de la sección estratigráfica Puerto Piñones (Jurásico Superior) del área de Saltillo, Coahuila, México. Unpublished M. Sc. Thesis, Posgrado en Ciencias de la Tierra, Universidad Nacional Autónoma de México, D. F., México.

López-Palomino, I., Villaseñor, A. B., and Olóriz, F. 2006. Primer registro del género Vinalesphinctes (Ammonitina) en el Oxfordiano de México: Significación bioestratigráfica y consideraciones paleobiogeográficas en el Jurásico Superior de América. Revista Mexicana de Ciencias Geológicas, 23(2):162-183.

Moliner, L. 2009. Ataxioceratinae (Ammonitina) del Kimmeridgiense inferior en el NE de la provincia de Teruel (Cordillera Ibérica oriental y Maestrazgo). PhD Thesis, Universidad de Granada, Godel Impresiones Digitales S. L., Granada, España. Digital copy available in: digibug.ugr.es/handle/10481/19690; bcct.unam.mx/tesis/3703; [e-copy for other links].

Moliner, L. and Olóriz, F. 2009.Correlation potential of the Upper Jurassic (lower Kimmeridgian) Platynota Chronozone deposits in northeastern Spain. GFF, 131(1):205-213.

Moliner, L. and Olóriz, F. 2010. New Lower Kimmeridgian ataxioceratin ammonite from the eastern Iberian
Chain, Spain: Systematic, biogeographic and biostratigraphic relevance. Acta Palaeontologica Polonica, 55(1):99-110.

Moor, E. 2009. Oxydiscites und Cymaceras vom Schaffhauser Randen. Mitteilungen der naturforschenden Gesellschaft; Schaffhausen, 49:1-36.

Olóriz, F. 1987. El significado biogeográfico de las plataformas mexicanas en el Jurásico superior. Consideraciones sobre un modelo eco-evolutivo. Revista de la Sociedad Mexicana de Paleontología, 1(1):219247.

Olóriz, F. 1992. North-central and eastern Mexico, p. 100-107. In Westermann, G.E.G. (ed.), The Jurassic of the Circum-Pacific, part 3, Regional Geology and Stratigraphy, Meso-America, Cambridge University Press, New York.

Olóriz, F. and Villaseñor, A.B. 1999. New microconchiate Hybonoticeras from Mexico. Geobios, 32:561-573.

Olóriz, F. and Villaseñor, A.B. 2006. Ceratosphinctes (Ammonitina, Kimmeridgian) in Mexico: from rare but typical inhabitant of west-Tethyan epioceanic and epicontinental waters to a widespread ammonite genus. Geobios, 36:255-266.

Olóriz, F., Villaseñor, A.B., and González-Arreola, C. 1997. Factors controlling upper Jurassic ammonite assemblages in north-central Mexico. Lethaia, 30:337-351.

Olóriz, F., Villaseñor, A.B., and González-Arreola, C. 2000. Geographic control on phenotype expression. The case of Hybonoticeras mundulum (Oppel) from the Mexican Altiplano. Lethaia, 33:157-174.

Olóriz, F., Villaseñor, A.B., and González-Arreola, C.2003. Major lithostratigraphic units in landoutcrops of north-central Mexico and the subsurface along the northern rim of Gulf of Mexico Basin (Upper Jurassic-lowermost Cretaceous): A proposal for correlation of tectono-eustatic sequences. Journal of South American Earth Sciences, 16:119-142.

Olóriz, F., Villaseñor, A.B., González-Arreola, C., and Westermann, G.E.G. 1990. Las plataformas mexicanas durante el Jurásico Superior. Un ejemplo de áreas de recepción en biogeografía, p. 277-287. In Civis Llovera, J. and Flores Villarejo, J.A. (eds.), 1988 Actas de Paleontología, IV Jornadas de Paleontología, Salamanca, España.

Olóriz, F., Villaseñor, A.B., and Grajales-Nishimura, M. 2010. New finding of genus Gregoryceras Spath 1924 (Ammonitina) from SE Mexico, Veracruz, p. 112-114. In Ruiz-Omeñaca, J.I., Piñuela, L., and García-Ramos, J.C. (eds.), 2010 Comunicaciones del V Congreso del Jurásico de España. Museo del Jurásico de Asturias (MUJA), Colunga, España.

Schairer, G. 2000. Die Ammoniten des Schurfs von Mantlach (Oberoxfordium-Unterkimmeridgium, Südliche Frankenalb, Bayern). Allgemeines und die Ammonitenfauna aus Bank 60. Mitteilungen der Bayerischen Staatssammlung für Paläontologie und Historische Geologie,40:81-107. 
Schick, H.W. 2000. The stratigraphical significance of Cymaceras guembeli for the boundary between Platynota Zone and Hypselocyclum Zone, and the correlation between Swabian and Franconian Alb. Zitteliana, A44:51-59.

Schneid, T. 1944. Uber Ataxioceratiden des nördlichen Frankenjura. Palaeontographica, Abt. A96:1-43.

Siemiradzki, J. 1898-1899. Monographische Beschreibung der Ammonitengattung Perisphinctes. Palaeontographica, 45:69-352.

Villaseñor, A.B. 1991. Aportaciones a la bioestratigrafía, basada en fauna de ammonites, de la sucesión del Jurásico superior (Kimmeridgiano-Tithoniano) del área de Mazapil, Zacatecas, México. Unpublished PhD Thesis, Facultad de Ciencias, Universidad Nacional Autónoma de México, D. F., México.

Villaseñor, A.B. and Olóriz, F. 2004. First occurrence of genus Pseudohimalayites Spath (Ammonitina) in Mexico, p. 151. In Abstracts. Sixth International Symposium Cephalopods-Present and Past. Fayetteville, Arkansas, USA.

Villaseñor, A.B. and Olóriz, F. 2010. Biomarkers for a Widespread Tethyan Flooding on Mexican Shelves during the Early Tithonian, p. 294-296. In Yusheng, Z., Jingeng, S., Xiaoqiao, W., Yanhong, P., and Yongdong, W. (eds.), Earth Science Frontiers-Short papers for the 8th International Congress on the Jurassic System, Special Issue, 17.

Villaseñor, A.B., Moliner, L., and Olóriz, F. 2014. Revisiting the record of genus Ataxioceras in Mexico, $\mathrm{p}$. 882. In Abstract volume. 4th International Palaeontologial Congress, Mendoza, Argentina.

Villaseñor, A.B., Moliner, L., and Olóriz, F. 2015. Schneidia zacatense sp. nov. First population level study of Ataxioceratinae from the Lower Kimmeridgian in northern Mexico-Biostratigraphic and palaeobiogeographic significance. Journal of South American Earth Sciences, 63:217-243.
Villaseñor, A.B. Olóriz, F. and González-Arreola, C. 2000. Recent advances in Upper Jurassic (Kimmeridgian-Tithonian) ammonite biostratigraphy of North-Central Mexico Based on recently collected ammonite assemblages. GeoResearch Forum, 6:249-262.

Villaseñor, A.B. Olóriz, F. and González-Arreola, C. 2003. First record of the genus Simocosmoceras Spath, 1925, Ammonitina, in Mexico, Biostratigraphic and palaeobiogeographic interpretation. GFF, 125:49-56.

Villaseñor, A.B. Olóriz, F. and González-Arreola, C. 2011. Lower Tithonian microconchiate simoceratins from eastern Mexico: Taxonomy, biostratigraphy, and palaeobiogeography. Acta Palaeontologica Polonica, 56(1):133-158.

Villaseñor, A.B., Olóriz, F., and López-Palomino, I. 2002. The finding of the ammonite genus Gregoryceras (Ammonitina) from Mexico, p. 191. In Martire, L. (ed.), 6th International Symposium on the Jurassic System, Palermo.

Villaseñor, A.B., Olóriz, F., and López-Palomino, I. 2004. Inner whorls of Gregoryceras (Ammonitina, Peltoceratinae) as the first occurrence of the genus in Mexico. Rivista Italiana di Paleontologia e Stratigrafia, 110(1):249-254.

Villaseñor, A.B., Olóriz, F., López-Palomino, I., and López-Caballero, I. 2012. Updated ammonite biostratigraphy from Upper Jurassic deposits in Mexico. Revue de Paléobiologie, Volume Spécial, 11:249267.

Wegele, L. 1929. Stratigraphische und faunistische Untersuchungen im Oberoxford und Unterkimmeridge Mittelfrankens. Palaeontographica, 71:117-210; 72:1-94.

Ziegler, B. 1983. Introduction to Palaeobiology: General Palaeontology. Ellis Horvood. Chichester. 